\title{
Knowledge, Attitude, Gender and Their Association Towards Online Learning Behavior Among Medical Students During Covid-19 Pandemic
}

\author{
Dasti Anditiarina $^{1 *}$, Artha Budi Susila Duarsa ${ }^{1}$, Ayu Anulus ${ }^{1}$ \\ ${ }^{1}$ Faculty of Medicine, Al-Azhar Islamic University \\ ${ }^{*}$ Corresponding author. Email: dr.dastianditiarina@gmail.com
}

\begin{abstract}
All universities during pandemic Covid-19, including faculty of medicine, have moved to online learning. The ability of students to learn is as much influenced by their inter-and intra-personal behavior as by their academic abilities. This study aimed to examine the association between knowledge, attitude, and gender towards online learning behavior using path analysis. A cross-sectional study was conducted at the Al-Azhar Islamic University, Mataram, West Nusa Tenggara. A total of 260 medical students was enrolled in this study. The dependent variable was online learning behavior. The independent variables were knowledge, attitude, and gender. Data were collected using questionnaire and analyzed using path analysis. The online learning behavior was directly affected and has a positive effect on good knowledge $(\mathrm{b}=0.58 ; 95 \% \mathrm{CI}=0.13$ to $1.15 ; \mathrm{p}=0.045)$, positive attitude $(\mathrm{b}=0.75 ; 95 \% \mathrm{CI}=0.20$ to $1.30 ; \mathrm{p}=0.008)$, and gender $(\mathrm{b}=0.65 ; 95 \% \mathrm{CI}=0.09$ to $1.21 ; \mathrm{p}=0.024)$. The online learning behavior was indirectly influenced by attitude and knowledge. This study concluded that online learning behavior is directly and positively affected by gender, knowledge, and attitude. Attitude and knowledge have indirectly influenced the behavior of online learning.
\end{abstract}

Keywords: online learning, behavior, path-analysis.

\section{INTRODUCTION}

Since World Health Organization (WHO) declared Covid-19 as a pandemic, the Government of Indonesia based on Government Regulation Number 21 of 2020 has decided to implement large-scale social restrictions (PSBB) in Indonesia. PSBB has also been implemented in West Nusa Tenggara since 5 June 2020. PSBB certainly affects the education sector because it has an impact on the learning process in all schools and universities in West Nusa Tenggara, especially medical students of Faculty of Medicine, Al-Azhar Islamic University [1].

Social restrictions affect the teaching and learning process so that distance learning/online learning is needed. Online learning is learning that does not require face-to-face learning between lecturers and students but utilizes internet networks or some other technology with accessibility, connectivity, flexibility, and the ability to generate various types of learning interactions $[2,3]$.

Online learning has many advantages, i.e., allows lecturers and students to interact in virtual classes that can be accessed anywhere and anytime, can make students more responsible, motivated and learn independently in understanding and completing assignments given by lecturers and increasing the role of students in learning $[3,4,5]$. However, online learning also has obstacles, i.e., internet network connection, limited quota, understanding in receiving material 
presented by lecturers [6,7]. The advantages and disadvantages of online learning, of course, directly or indirectly have an impact on the learning behavior of Faculty of Medicine, Al-Azhar Islamic University medical students.

During the Covid-19 pandemic, the online learning behavior of medical students must be examined because medical students are expected not only to increase expertise, but also to increase clinical and social skills. Therefore, online learning is a challenge; positive learning behavior must be maintained during online learning.

Learning behavior is influenced by several things. According to Febriyanto [8], behavior is influenced by genetic/endogenous factors and external factors. One of these genetic factors is gender, for example, male behavior based on rational / rational considerations, while in women on an emotional basis. In addition, according to Notoatmodjo (2010), predisposing factors are one of the factors that influence behavior. Predisposing factors are factors that facilitate a person's behavior, including knowledge and attitudes. Therefore, learning behavior is assumed to be influenced by knowledge (academic ability), attitudes and gender [9].

The factors that influence learning behavior need examined as a reference to improve student learning outcomes. Therefore, this study is needed to examine the influence of knowledge, attitudes and gender, also their associations on online learning behavior among medical students during the Covid-19 pandemic.

\section{SUBJECTS AND METHOD}

\subsection{Study Design}

This was a cross-sectional study carried out in JulyAugust 2020 in faculty of medicine, Al-Azhar Islamic University, Mataram, West Nusa Tenggara, Indonesia.

\subsection{Population and Sample}

The population of this study was all students from faculty of medicine, Al-Azhar Islamic University, Mataram, West Nusa Tenggara, Indonesia. This study involved 260 medical students who willing to participate in this study. The study subjects were selected using simple random sampling technique.

\subsection{Study Variables}

The dependent variable of this study was online learning behavior during Covid-19 pandemic e.g., active on class discussion, activate the camera, focus on learning, prepare for the study, and not access social media during online learning. The independent variables were knowledge, attitude, and gender.

\subsection{Study Instruments}

The data for this study was gathered using a Google form and an online questionnaire. Participants were encouraged but not compelled to participate. The link to the Google form was shared through a WhatsApp group. Knowledge and online learning behavior were using closed-item questionnaires with two options "Yes" and "No". Gender was divided as male and female. A set of closed-item questionnaires with five Likert Scale options were used to collect attitude data. 1 meant "strongly disagree," 2 meant "disagree," 3 meant "neutral," 4 meant "agree," and 5 meant "strongly agree."

\subsection{Data Analysis}

The data were converted from google form to Microsoft Excel and then imported to the STATA program version 13 . The data then analyzed using path analysis. Its purpose is to provide estimates of the magnitude and significance of the causal ties hypothesized between sets of variables.

\subsection{Research Ethic}

This study was permitted and conducted based on the research ethic from Ethics Committee of the Faculty of Medicine, Al-Azhar Islamic University with number of 30/EC/FK-06/UNIZAR/VIII/2020.

\section{RESULTS}

The following results of data processing using path analysis with Stata Program Version 13 presented in Figure 1.

\subsection{Model specification}

Model specification describes the relationship between the variables under study. The variables in this study contained four measured variables (observed variables), i.e., knowledge, attitudes, gender, and online learning behavior. The structural image can be seen in the following: 


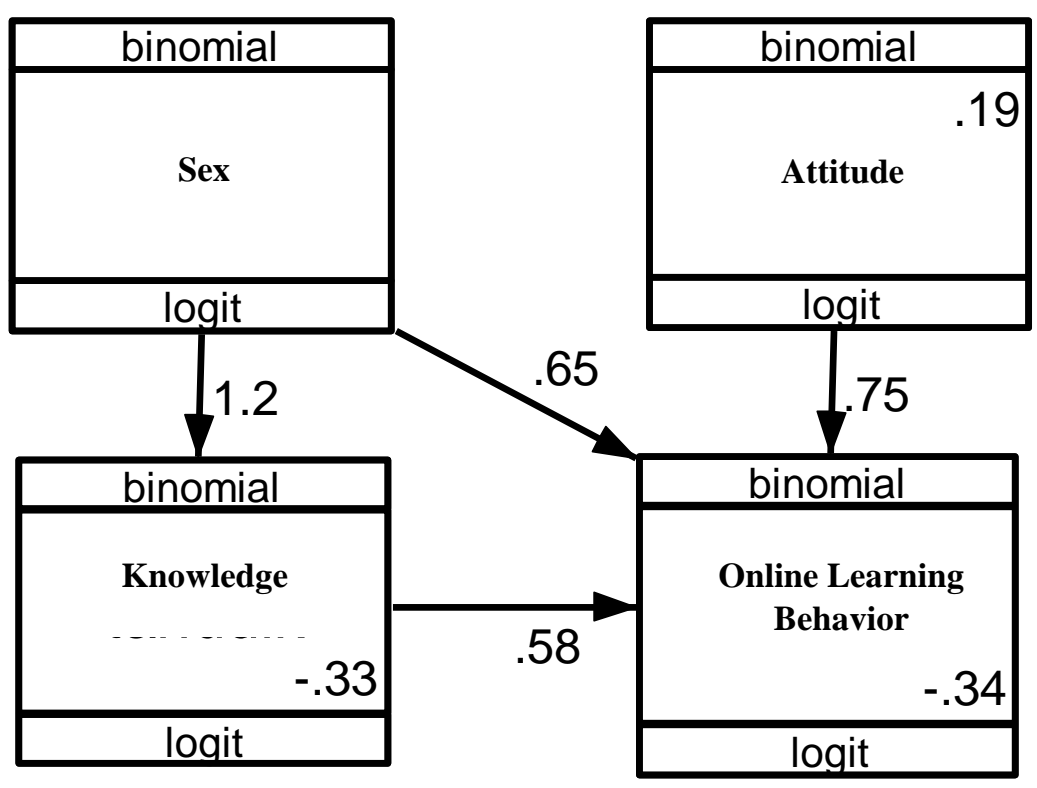

Figure 1. Path analysis of knowledge, attitude, gender, and their association towards online learning behavior among medical students during covid-19 pandemic.

\subsection{Model Identification}

Model identification was the number of measurable variables identified (exogenous variables, endogenous variables, and parameters to be estimated). At this stage, the degree of freedom (df) was calculated, which shows the path analysis can be done or not. The calculation formula was:

a. Number of measured variables: 4

b. Endogenous variables: 2

c. Exogenous variables: 3

d. Number of parameters: 4

The formula for degree of freedom is as follows:

df $=$ (number of measured variables $\mathrm{x}$ (number of measured variables +1$) / 2$ - (endogenous variables + exogenous variable + number of parameters) $\mathrm{df}=(4 \times(4+1) / 2-(2+3+4)$

$\mathrm{df}=10-9$

$\mathrm{df}=1$

Path analysis can be done if $\mathrm{df} \geq 0$, while the identification of the model in above, the $\mathrm{df}$ value is 1 and it is called over identified path analysis, which means that path analysis can be carried out. The suitability of the model path analysis created by researchers based on theory are checked using Stata Program Version 13.

\subsection{Estimation of parameters}

Table 1. showed that there was a direct effect from knowledge to behavior. Medical students who had high knowledge will increase the good behavior by 0.58 units higher than students with low knowledge $(\mathrm{b}=0.58$; $95 \% \mathrm{CI}=0.13$ to $1.15 ; \mathrm{p}<0.045)$. 
Table 1. Results of path analysis

\begin{tabular}{|c|c|c|c|c|c|c|}
\hline \multirow{2}{*}{\multicolumn{2}{|c|}{ Endogenous Variable }} & \multirow[b]{2}{*}{ Exogenous Variable } & \multirow{2}{*}{$\begin{array}{c}\text { Path } \\
\text { coefficient }\end{array}$} & \multicolumn{2}{|c|}{$95 \%$ CI } & \multirow[b]{2}{*}{$\mathbf{p}$} \\
\hline & & & & Lower & $\begin{array}{l}\text { Upper } \\
\text { Limit }\end{array}$ & \\
\hline \multicolumn{7}{|l|}{ Direct effect } \\
\hline Behavior & $\stackrel{\leftarrow}{\leftarrow}$ & $\begin{array}{l}\text { Knowledge } \\
\text { Attitude } \\
\text { Gender }\end{array}$ & $\begin{array}{l}0.58 \\
0.75 \\
0.65\end{array}$ & $\begin{array}{l}0.13 \\
0.20 \\
0.09\end{array}$ & $\begin{array}{l}1.15 \\
1.30 \\
1.21\end{array}$ & $\begin{array}{l}0.045 \\
0.008 \\
0.024\end{array}$ \\
\hline \multicolumn{7}{|l|}{ Indirect effect } \\
\hline Attitude & $\leftarrow$ & Knowledge & 0.86 & 0.36 & 1.36 & 0.001 \\
\hline Knowledge & $\leftarrow$ & Gender & 1.21 & 0.69 & 1.72 & $<0.001$ \\
\hline \multicolumn{7}{|l|}{ Log Likelihood= - 492.42} \\
\hline $\mathrm{N}$ observation $=260$ & & & & & & \\
\hline
\end{tabular}

There was a direct effect of attitude on online learning behavior, and it was statistically significant. Students with good attitudes increased good behavior by 0.75 units higher than students with bad attitudes $(\mathrm{b}=$ $0.75 ; 95 \% \mathrm{CI}=0.20$ to $1.30 ; \mathrm{p}=0.008)$.

There was a direct effect of gender on online learning behavior, and it was statistically significant. Female students increased good behavior by 0.65 units higher than male students $(b=0.65 ; 95 \% \mathrm{CI}=0.09$ to $1.21 ; \mathrm{p}=0.024)$.

There was an indirect effect of knowledge on online learning behavior, and it was statistically significant. Students who had high knowledge increased good behavior by 0.86 units higher than students with less knowledge $(b=0.86 ; 95 \% \mathrm{CI}=0.36$ to $1.36 ; \mathrm{p}=0.001)$.

There was an indirect effect of gender on knowledge and it was statistically significant. Female students increased good behavior by 1.21 units higher than male students $(b=1.21 ; 95 \% \mathrm{CI}=0.69$ to $1.72 ; \mathrm{p}<0.001)$.

\section{DisCUSSION}

Learning behavior is a method or technique that settles among students by reading books, doing assignments, and arranging time to complete activities [10]. According to Febriyanto (2016) behavior is influenced by genetic/endogenous and external factors. One of these genetic factors is gender, for example, male behavior based on rational considerations, while in female based on an emotional basis [8]. In addition, according to Notoatmodjo (2010), predisposing factors are one of the factors that influence behavior that facilitate a person's behavior, including knowledge and attitudes [9]. Therefore, online learning behavior is influenced by knowledge, attitudes, and gender.

This study proves that during online learning, the learning behavior of medical students at Faculty of Medicine, Al-Azhar Islamic University, Mataram, Indonesia, was influenced by knowledge, attitudes, and gender. Online learning behavior has a direct and positive effect on good knowledge $(b=0.58 ; 95 \% \mathrm{CI}=$
0.13 to $1.15 ; \mathrm{p}=0.045)$, positive attitude $(\mathrm{b}=0.75 ; 95 \%$ $\mathrm{CI}=0.20$ to $1.30 ; \mathrm{p}=0.008)$, and gender $(\mathrm{b}=0.65 ; 95 \%$ $\mathrm{CI}=0.09$ to $1.21 ; \mathrm{p}=0.024)$.

Knowledge is the result of human sensing or the result of someone knowing an object through the senses they have [9]. Knowledge in this study is related to the academic ability of students in the learning process at the medical faculty. Good academic ability has a positive effect on learning behavior of medical students during online learning. This is supported by Rachmi (2010), factors that influence learning behavior include internal factors, i.e., related to intelligence / academic ability [11].

A person's attitude can affect his learning behavior. Attitude is a reaction from a person to stimulus or object that is not yet an action but is a predisposition to the action of a behavior based on beliefs of existing norms among society [8,12]. According to Suharyat (2009), attitudes can influence behavior thorough reasoned and impactful decision-making process. Therefore, someone with a positive attitude has a positive impact on learning behavior and vice versa [12].

Gender is the difference in opportunities, roles, and responsibilities between male and female as a result of social construction among family and community life [13]. This study shows that gender influences online learning behavior. According to Tangkudung (2014), male is easier to adjust in the teaching and learning process than female, but on the other hand, female is easier in terms of socializing with other lecturers and students [13]. According to Atkinson et al. (1999) in the cognitive aspect, male excel in visual-spatial, logicalmathematical abilities, while female excel in verbal, practical, and concrete abilities; in the behavior aspect, male tend to be initiative and goal oriented, while female tend to be reactive and task-oriented. In terms of affective, male is more aggressive and rational, while female is more passive and emotional [14]. 


\section{CONCLUSION}

This study concluded that online learning behavior is directly and positively affected by gender, knowledge, and attitude. Attitude and knowledge have indirectly influenced the behavior of online learning. Further study is needed to enhance the results so the data can be generalized to all medical students related to their online learning behavior.

\section{AUTHORS 'CONTRIBUTIONS}

Dasti Anditiarina, Artha Budi Susila Duarsa, and Ayu Anulus were contributed equally for this study. All authors were designed the study problem, analyzed the data, and made the manuscript.

\section{REFERENCES}

[1] BPK RI. Peraturan Pemerintah Nomor 21 Tahun 2020. Pembatasan Sosial Berskala Besar dalam Rangka Percepatan Penanganan Corona Virus Disease 2019 (Covid-19). 31 Maret 2020. Lembaran Negara Republik Indonesia Tahun 2020 Nomor 21. Jakarta. https://peraturan.bpk.go.id/Home/Details/ 135059/pp-no-21-tahun-2020

[2] Joi L. Moore, Camille Dickson-Deane, Krista Galyen, e-Learning, online learning, and distance learning environments: Are they the same? The Internet and Higher Education, Volume 14, Issue 2, 2011, pp 129135, https://doi.org/10.1016/j.iheduc.2010.10.001.

[3] Bentley, Y, Selassie, H and Shegunshi, A. "Design and Evaluation of Student-Focused eLearning" The Electronic Journal of e-Learning Volume 10 Issue 1. 2012. pp 01-12. http://www.ejel.org/

[4] Sadikin, A., \& Hamidah, A.Pembelajaran Daring di Tengah Wabah Covid-19: (Online Learning in the Middle of the Covid-19 Pandemic). BIODIK. 2020. pp 214-224. https://doi.org/10.22437/bio.v6i2.9759

[5] Sakti, S \& N, Sulung. Analisis Pembelajaran di Masa Pandemik Covid 19 (Literatur Review). Jurnal Endurance: Kajian Ilmiah Problema Kesehata. 2020. pp 496-513. ejournal.1ldikti10.id

[6] Ulfa, Z.D, Mikdar U.Z. Dampak Pandemi Covid-19 terhadap Perilaku Belajar, Interaksi Sosial dan Kesehatan bagi Mahasiswa FKIP Universitas Palangka Raya. Jossae (Journal of Sport Science and Education). 2020. pp 124-138. DOI: http://dx.doi.org/10.26740/jossae.v5n2.p124-138

[7] Yuliangsih, I, Parlindungan D.P. Persepsi Mahasiswa Pendidikan Olahraga Terhadap Perkuliahan Daring Selama Pandemi Covid-19. Gelanggang Olahraga Jurnal Pendidikan Jasmani dan Olahraga. 2020. pp 31-46. DOI: https://doi.org/10.31539/jpjo.v4i1.1467

[8] Febriyanto, M.A.B. Hubungan Antara Pengetahuan Dan Sikap Dengan Perilaku Konsumsi Jajanan Sehat
Di Mi Sulaimaniyah Mojoagung Jombang. Skripsi. Fakutlas Kesehatan Masyarakat Universitas Airlangga. 2016. http://repository.unair.ac.id/id/ eprint $/ 46023$

[9] Notoatmodjo, S. 2010. Ilmu Perilaku Kesehatan. Jakarta: Rineka Cipta. ISBN/ISSN: 978-979-518983-1. http://repo.unikadelasalle.ac.id/index.php?p=s how_detail\&id=6161\&keywords=

[10] Aminoto, Tugiyo. "Penerapan Media E-Learning Berbasis Schoology untuk Meningkatkan Aktivitas dan Hasil Belajar Materi Usaha dan Energi di Kelas XI SMA N 10 Kota Jambi." Sainmatika: Jurnal Sains dan Matematika Universitas Jambi, vol. 8, no. 1, 2014. https://media.neliti.com/media/publication s/221167-penerapan-media-e-learning-berbasisscho.pdf

[11] Suharyat, Y. Hubungan Antara Sikap, Minat Dan Perilaku Manusia. Journal Region1. 2009. pp:1-19. https://www.academia.edu/download/37999753/arti cle.php.pdf

[12] Tangkudung, J.P.M. Proses Adaptasi Menurut Jenis Kelamin dalam Menunjang Studi Mahasiswa Fisip Universitas Sam Ratulangi. Journal "Acta Diurna". 2014. pp 1-11. https://ejournal.unsrat.ac.id/index. php/actadiurnakomunikasi/article/view/6225

[13] Atkinson, Rita L., Richard C. Atkinson., Ernest R. Hilgard. Pengantar Psikologi. Jakarta: Erlangga. 1999. pp 1-496. 